\title{
Discovery of Novel Bruton's Tyrosine Kinase (BTK) Inhibitors Bearing a N,9-Diphenyl-9H-purin-2-amine Scaffold
}

\author{
Yang Ge, ${ }^{\dagger, \|}$ Yue Jin, ${ }^{\dagger, \|}$ Changyuan Wang, ${ }^{\dagger}$ Jianbin Zhang, ${ }^{\dagger}$ Zeyao Tang, $^{\dagger}$ Jinyong Peng, $^{\dagger}$ Kexin Liu, ${ }^{\dagger}$ \\ Yanxia $\mathrm{Li}^{\ddagger}{ }^{\dagger}$ Youwen $\mathrm{Zhou},{ }^{\S}$ and Xiaodong $\mathrm{Ma}^{*}{ }^{\dagger}$ \\ ${ }^{\dagger}$ College of Pharmacy, Dalian Medical University, Dalian 116044, P. R. China \\ ${ }^{\ddagger}$ Respiratory Department, The First Affiliated Hospital of Dalian Medical University, Dalian 116011, P. R. China \\ ${ }^{\S}$ Department of Dermatology and Skin Science, University of British Columbia, Vancouver, BC V5Z 4E8, Canada
}

\section{Supporting Information}

\begin{abstract}
Based on the pyrimidine skeleton of EGFR ${ }^{\mathrm{T} 790 \mathrm{M}}$ inhibitors, a series of $\mathrm{N}, 9$-diphenyl-9H-purin-2-amine derivatives were identified as effective BTK inhibitors. Among these compounds, inhibitors $10 \mathrm{~d}, 10 \mathrm{i}$, and $10 \mathrm{j}$, possessing $\mathrm{IC}_{50}$ values of $0.5,0.5$, and $0.4 \mathrm{nM}$, displayed anti-BTK kinase activity that was as potent as the reference compounds. In particular, compound $10 \mathrm{j}$ suppressed the proliferation of two typical B-cell leukemia cell lines expressing high levels of BTK with concentrations of 7.75 and $12.6 \mu \mathrm{M}$. The activity of the subject compound as determined by the CCK- 8 method and apoptosis analysis validated that inhibitor $10 \mathbf{j}$ is slightly more potent than AVL-292 and ibrutinib. The results of these experimental explorations suggested that $\mathbf{1 0} \mathbf{j}$ could serve as a valuable molecule for control of leukemia pending further developments
\end{abstract}

KEYWORDS: Leukemia, BTK inhibitor, purin, synthesis, activity

B ruton's tyrosine kinase (BTK) is a member of the Tec family of nonreceptor tyrosine kinases that play a key role in the B-cell signaling pathway linking cell surface B-cell receptor (BCR) stimulation to downstream intracellular responses. ${ }^{1,2}$ The deregulation of BTK has been observed in numerous B-cell-derived malignancies, including acute lymphoblastic leukemia (ALL), chronic lymphocytic leukemia (CLL), non-Hodgkin's lymphoma (NHL), mantle cell lymphoma (MCL), Waldenstrom's macroglobulinemia (WM), and multiple myeloma (MM). ${ }^{3,4}$ In 2013, ibrutinib was approved by the US Food and Drug Administration (FDA) as the first-in-class human BTK-inhibitor (1, Figure 1) to demonstrate clinical effectiveness and tolerability in early clinical trials for the treatment of mantle cell lymphoma. ${ }^{5}$ Subsequently, it was also applied to treat chronic lymphocytic leukemia (2014) and Waldenstrom's macroglobulinemia (2015), a form of nonHogkin's lymphoma. ${ }^{6-8}$

Recently, a number of covalent and noncovalent BTK inhibitors including GS-4059 (2) (ClinicalTrials.gov identifier: NCT02457559), ${ }^{9}$ RN486 (3), ${ }^{10,11}$ AVL-292 (4) (ClinicalTrials.gov identifier: NCT01975610), ${ }^{12}$ HM71224 (5) (ClinicalTrials.gov identifier: NCT01765478), ${ }^{13}$ and PLS-123 (6) ${ }^{14}$ have been advanced to preclinical to clinical trials (Figure 1). Notably, all currently reported covalent BTK inhibitors act primarily on the amino acid Cys481 located in the kinase hinge segment, ${ }^{15}$ which is also the preserve of all five Tec-family kinases, JAK3, EGFR, HER2, HER4, and BLK. In terms of an epidermal growth factor receptor (EGFR), the binding for this resides at Cys797, while it is found at Cys909 in JAK3. ${ }^{16-18}$ Using this strategy, the novel pyrimidine scaffold, included in molecules WZ4002 (7), ${ }^{17}$ rociletinib (8), ${ }^{19}$ and osimertinib $(9)^{20}$ has been found to be a potent inhibitor that can overcome nonsmall-cell lung cancer (NSCLC) drug resistance with T790M mutation (Figure 2).

In an effort to develop more effective $\mathrm{EGFR}^{\mathrm{T} 790 \mathrm{M}}$ inhibitors, we previously designed and synthesized a series of $\mathrm{N}, 9$ diphenyl-9H-purin-2-amine analogues $(\mathbf{1 0 a}-\mathbf{m}$, Figure 3) by applying the conformational constraint strategy, which is an effective method to improve ligand selectivity for a molecular target. $^{21-23}$ Unfortunately, the assayed results showed that these synthesized compounds exhibited nearly 10-fold less potency against $\mathrm{H} 1975$ cells harboring the $\mathrm{EGFR}^{\mathrm{T} 790 \mathrm{M}}$ mutant. In addition, they also displayed weak activity against the JAK3 enzyme with $\mathrm{IC}_{50}$ values of about $100 \mathrm{nM}$. Fortunately, the evaluation of these compounds for the inhibition of the BTK target provided exciting results, where several molecules appeared to inhibit BTK kinase at concentrations of $10 \mathrm{nM}$. Therefore, in this report, the potential of these molecules as BTK inhibitors is detailed by describing their synthesis, biological activity, and molecular simulation.

Received: June 11, 2016

Accepted: September 21, 2016

Published: September 21, 2016 

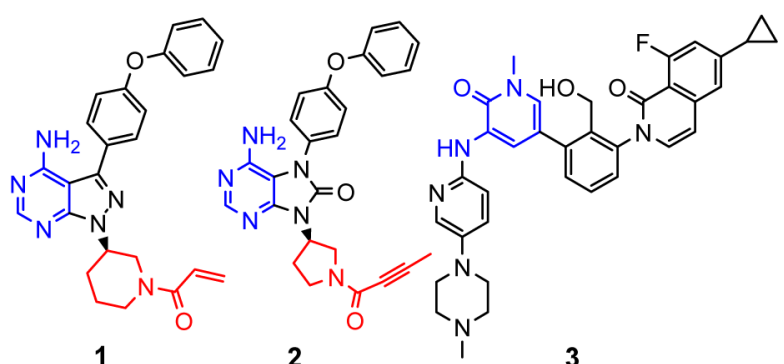

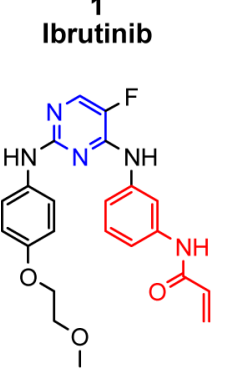

4

AVL-292
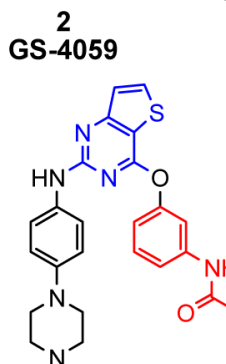

5
HM71224

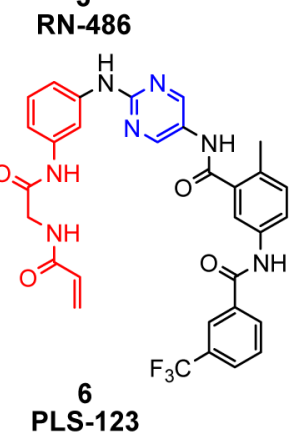

Figure 1. Structures of exemplary BTK inhibitors.

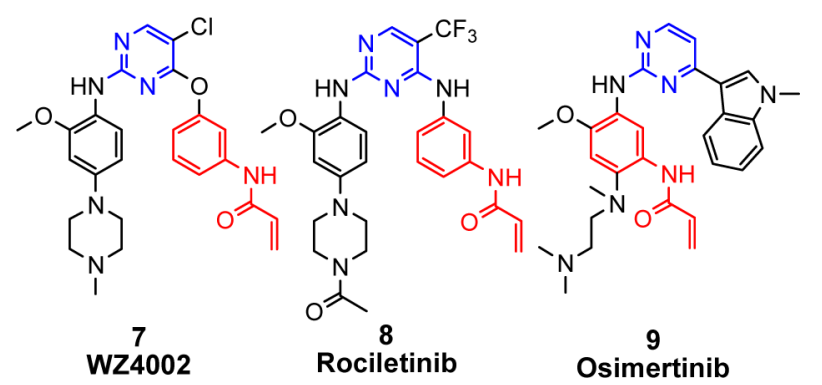

Figure 2. Structures of novel EGFR ${ }^{\mathrm{T} 790 \mathrm{M}}$ inhibitors.

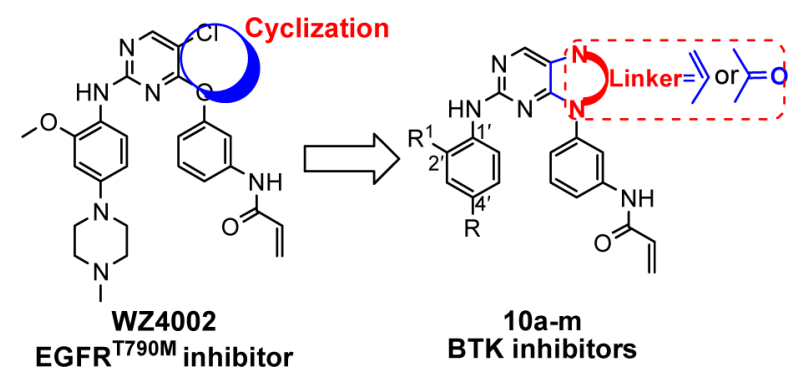

Figure 3. Designed strategy of title molecules.

The synthesis of title compounds $\mathbf{1 0 a}-\mathbf{m}$ is shown in Scheme $1 .^{23,24}$ In this synthesis, commercially available 2,4dichloro-5-nitropyrimidine $\mathbf{1 1}$ was reacted with the protected tert-butyl 3-aminophenylcarbamate in the presence of $\mathrm{N}, \mathrm{N}$ diisopropylethylamine (DIPEA) to produce 2-chloro-4-(3-tertbutoxycarbonyl)phenylamino)-5-nitropyrimidine 12 as a white solid. After coupling with various anilines, the pyrimidine template (compounds 13a-k) was synthesized. Compounds $13 a-k$ were further deprotected with trifluoroactic acid and subsequently reacted with acryloyl chloride, to produce the key intermediates $15 \mathbf{a}-\mathbf{k}$. By reducing the nitro functionality in $\mathbf{1 5 a}-\mathbf{k}$ using $\mathrm{Fe}-\mathrm{NH}_{4} \mathrm{Cl}$ conditions, the anilines $16 \mathbf{a}-\mathbf{k}$ were prepared in excellent yields (52-68\%). Finally, compounds $16 \mathbf{a}-\mathbf{k}$ were treated with triethyl orthoformate or carbon-
Scheme 1. Synthetic Route of Title Compounds $10 \mathrm{a}-\mathrm{m}^{a}$<smiles>[R]c1ccc(Nc2ncc([N+](=O)[O-])c(Nc3cccc(NC(C)(C)C)c3)n2)c([R])c1</smiles><smiles>[R]c1cccc(Nc2ncc([N+](=O)[O-])c(Nc3cccc(Nc4ncc([N+](=O)[O-])c(Nc5cccc(NC(=O)C=C)c5)n4)c3[R1])n2)c1[R]</smiles>

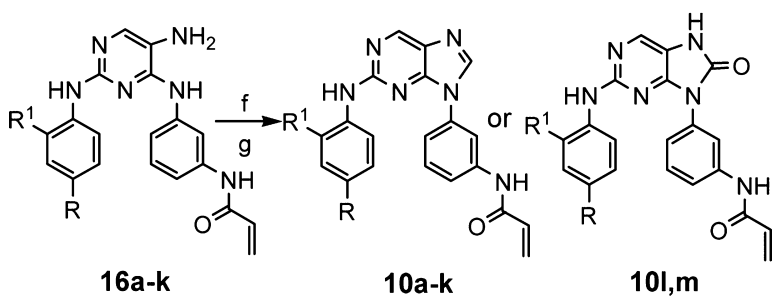

${ }^{a}$ Reagents and conditions: (a) $\mathrm{ArNH}_{2}$, DIPEA, 1,4-dioxane, rt, $2 \mathrm{~h}$, 91\%; (b) $\mathrm{ArNH}_{2}$, DIPEA, 1,4-dioxane, $60{ }^{\circ} \mathrm{C}, 2 \mathrm{~h}, 49-72 \%$; (c) trifluoroacetic acid, $\mathrm{CH}_{2} \mathrm{Cl}_{2}, 0{ }^{\circ} \mathrm{C}$ to $\mathrm{rt}, 62-85 \%$; (d) acryloyl chloride, $\mathrm{NaHCO}_{3}$, acetone, 10 min, 43-68\%; (e) $\mathrm{Fe}-\mathrm{NH}_{4} \mathrm{Cl}, \mathrm{MeOH}-\mathrm{H}_{2} \mathrm{O}, 2 \mathrm{~h}$, $80{ }^{\circ} \mathrm{C}, 52-68 \%$; (f) triethyl orthoformate, $2 \mathrm{~h}, 110{ }^{\circ} \mathrm{C}, 28-51 \%$; (g) carbonyldiimidazole, $\mathrm{CH}_{2} \mathrm{Cl}_{2}, 1 \mathrm{~h}, \mathrm{rt}, 32-44 \%$.

yldiimidazole to yield the desired 2,8-dianilinopurine derivatives $10 \mathbf{a}-\mathbf{m}^{25}$

The newly synthesized $N, 9$-diphenyl-9H-purin-2-amine derivatives were evaluated as BTK inhibitors in enzyme-based and cell-based assays. For comparison, AVL-292 (phase III) and the approved drug ibrutinib were also evaluated as references. All these results are reported in Table 1. Among these inhibitors, compounds $10 \mathrm{~d}, 10 \mathrm{i}$, and $10 \mathbf{j}$ displayed the strongest potency to inhibit the $\mathrm{BTK}$ kinase, possessing $\mathrm{IC}_{50}$ values of $0.5,0.5$, and $0.4 \mathrm{nM}$, respectively. Apparently, they were as potent as AVL-292 $\left(\mathrm{IC}_{50}=0.6 \mathrm{nM}\right)$ and ibrutinib $\left(\mathrm{IC}_{50}\right.$ $=0.3 \mathrm{nM}$ ) for suppressing the BTK target. The activity tested in kinase level revealed that the sulfonamide group at the N-4 position of the piperazine ring was unfavorable to interact with BTK. For instance, compounds $10 \mathrm{f}$ and $10 \mathrm{~h}$, with $\mathrm{IC}_{50}$ values of 17.1 and $13.2 \mathrm{nM}$, were 57 - to 22-fold less potent for suppressing the BTK target than the reference compounds. From these tested results, it also can be seen that compounds 10c, 10e, and $10 \mathrm{~g}$, containing a $C-2^{\prime}$ methoxy-substituted phenyl amino at $C-2$ position of pyrimidine core, significantly lost the capacity for inhibiting BTK $\left(\mathrm{IC}_{50}\right.$ values of more than $100 \mathrm{nM}$ ). It was speculated that the bulky methoxy group caused the steric exclusion of the BTK binding pocket, which greatly decreased the binding forces between the synthesized compounds and the BTK target. However, compound 10k, which was produced by removing the methoxy group to the $C$ 4 position of the phenyl ring, displayed improved suppression activity $\left(\mathrm{IC}_{50}=97.1 \mathrm{nM}\right)$ for inhibiting the BTK kinase. Introduction of a long side chain to the phenyl ring, such as 3morpholin-4-ylpropoxy group (compound 10j), is quite beneficial in inhibiting the $\mathrm{BTK}\left(\mathrm{IC}_{50}=0.4 \mathrm{nM}\right.$ ) enzyme. With regard to compounds 101 and $10 \mathrm{~m}$, due to the presence 
Table 1. Biological Activity of Our Synthesized Compounds ${ }^{a}$

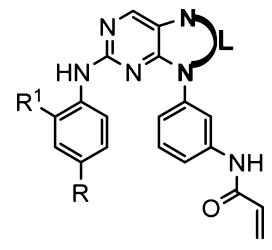

\begin{tabular}{|c|c|c|c|c|c|}
\hline \multirow{2}{*}{ Compd } & \multirow[t]{2}{*}{$\mathrm{R}$} & \multirow[t]{2}{*}{$\mathrm{R}^{1}$} & \multirow[t]{2}{*}{$\mathrm{L}$} & $\begin{array}{c}\text { Enzymatic } \\
\text { activity } \\
\left(\mathrm{IC}_{50}, \mathrm{nM}\right) \\
\end{array}$ & $\begin{array}{r}\text { Antiprolifer } \\
\text { ation activity } \\
\left(\mathrm{IC}_{50}, \mu \mathrm{M}\right)^{\mathrm{b}}\end{array}$ \\
\hline & & & & JAK3 & Ramos \\
\hline
\end{tabular}

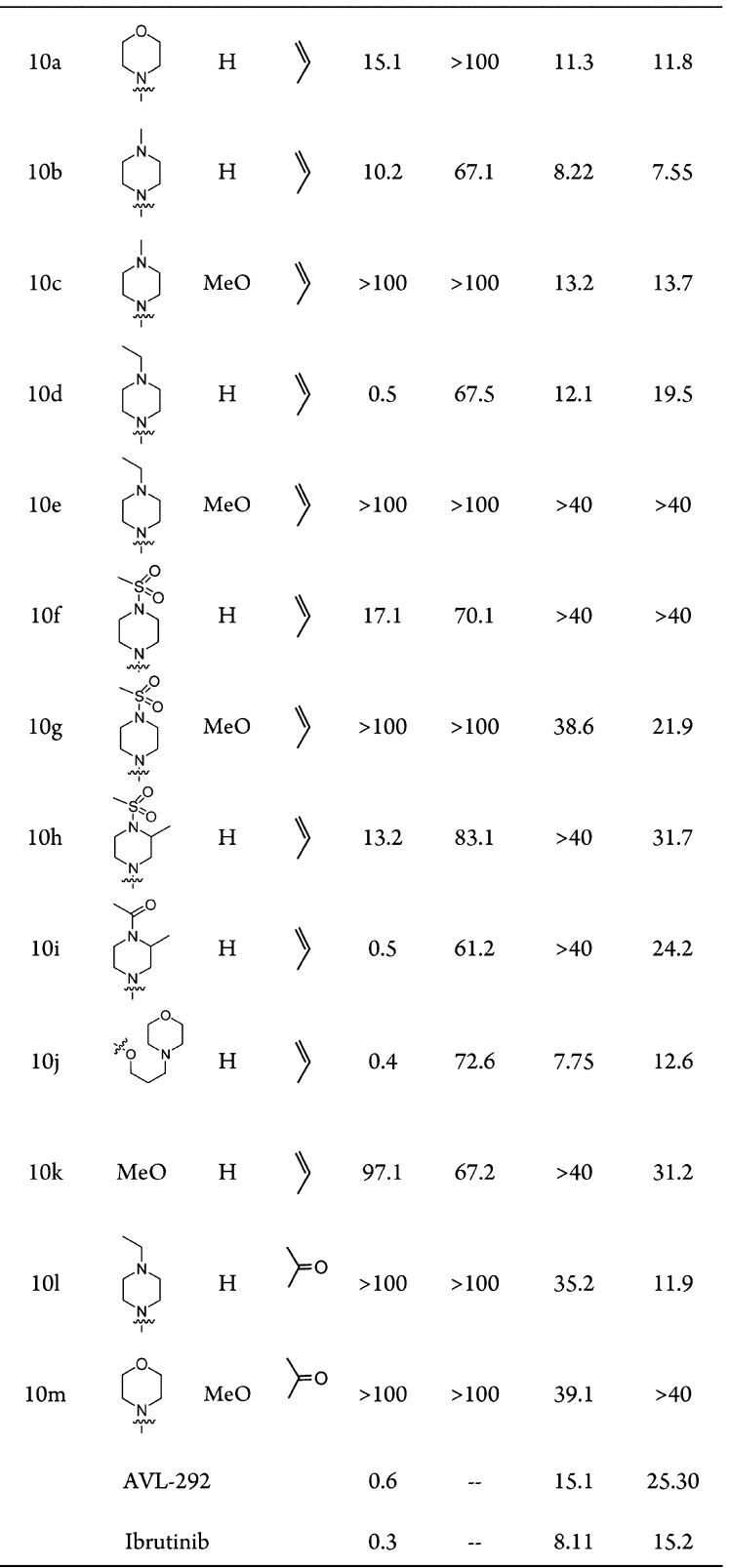

${ }^{a}$ Data represent the mean of at least three separate experiments. ${ }^{b}$ Dose-response curves were determined at five concentrations. The $\mathrm{IC}_{50}$ values are the concentrations in micromolar needed to inhibit cell growth by $50 \%$ as determined from these curves.

of a hydroxyl group on the pyrimidine core, they exhibited very weak anti-BTK activity, with $\mathrm{IC}_{50}$ values of more than $100 \mathrm{nM}$.
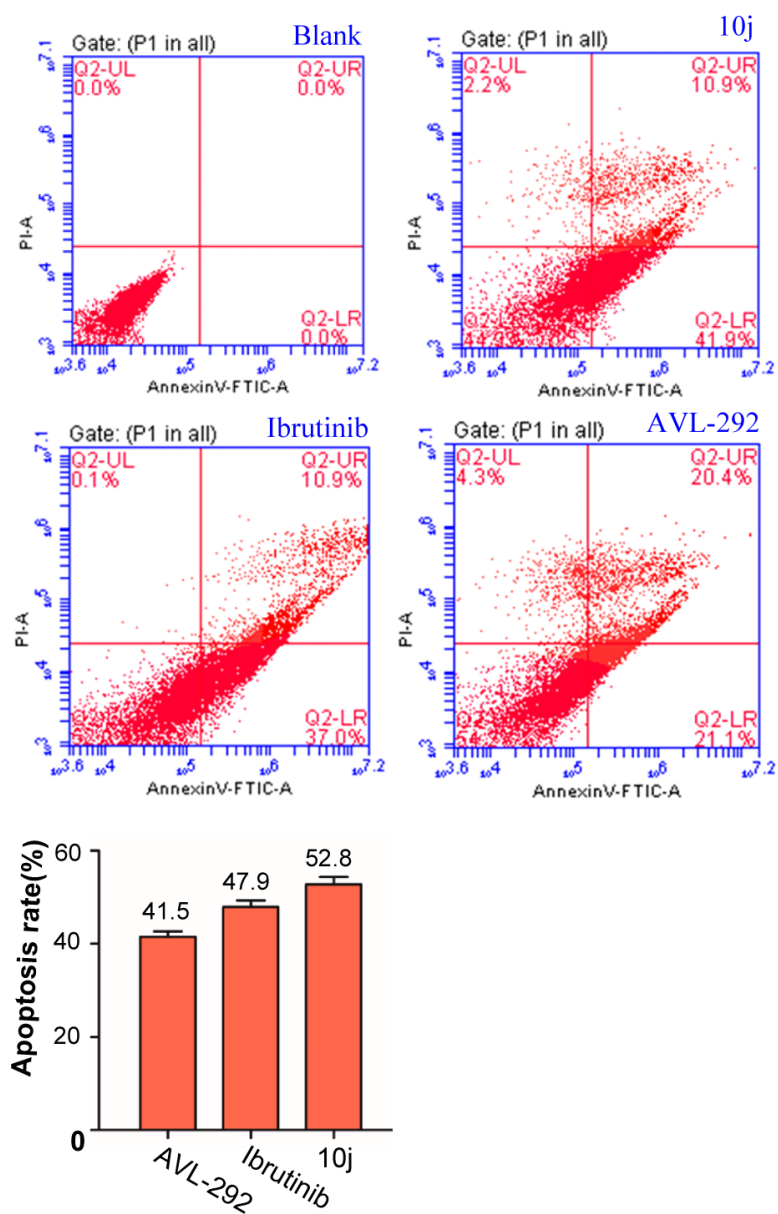

Figure 4. Compound $10 \mathrm{j}$ induced ramos cell apoptosis in vitro. The cells were incubated with the indicated concentrations of $10 \mathrm{j}$ for $48 \mathrm{~h}$, and the cells were stained with annexin V/FTIC, followed by flow cytometry analysis. One representative experiment is shown. $p<0.05$.

In addition, all these compounds were also evaluated for their effects on the JAK3 kinase. As shown in Table 1, most of these analogues were not effective in inhibiting JAK3, with inhibition $\mathrm{IC}_{50}$ values ranging from 61.2 to $83.1 \mathrm{nM}$. Interestingly, compounds $10 \mathrm{i}\left(\mathrm{IC}_{50}=61.2 \mathrm{nM}\right)$ and $10 \mathrm{j}\left(\mathrm{IC}_{50}=72.6 \mathrm{nM}\right)$, which have very low $\mathrm{IC}_{50}$ values for inhibiting $\mathrm{BKT}$ kinase $(0.5$ and $0.4 \mathrm{nM}$, respectively), appeared to be quite potent against JAK3 kinase, suggesting that further modification of this scaffold may produce a potent JAK3 and BTK dual inhibitor.

Further testing of these molecules against B-cell leukemia cell lines (ramos and raji) using CCK- 8 method are summarized in Table $1 .^{26}$ As shown in this table, compound $\mathbf{1 0 j}$, the active inhibitor against the BTK kinase $\left(\mathrm{IC}_{50}=0.4 \mathrm{nM}\right)$, was also very potent against the B-cell leukemia cell lines with $\mathrm{IC}_{50}$ values of $7.75 \mu \mathrm{M}$ against ramos cell line and $12.6 \mu \mathrm{M}$ against raji cell line. Although analogue $\mathbf{1 0 b}$ had a lower $\mathrm{IC}_{50}$ value $(10.2 \mathrm{nM})$ than $10 \mathbf{j}$ in kinase-based evaluation, it exhibited a strong suppression of these cancer cell lines ( $\mathrm{IC}_{50}$ values of 8.22 and $7.55 \mu \mathrm{M}$, respectively). Interestingly, analogue 10c, which contains a methoxy group at $\mathrm{C}-2$ position of the phenyl ring, exhibited nearly no anti-BKT activity (with an $\mathrm{IC}_{50}$ value of more than $100 \mathrm{nM}$ ), but possessed moderate $\mathrm{IC}_{50}$ value of 13.2 $\mu \mathrm{M}$ against the ramos cell line and $\mathrm{IC}_{50}$ value of $13.7 \mu \mathrm{M}$ against the raji cell line, hinting that 10c might be employing a new mechanism to inhibit the B-cell leukemia cell lines. It found that compound 10e with a methoxy group at the $C-2$ 

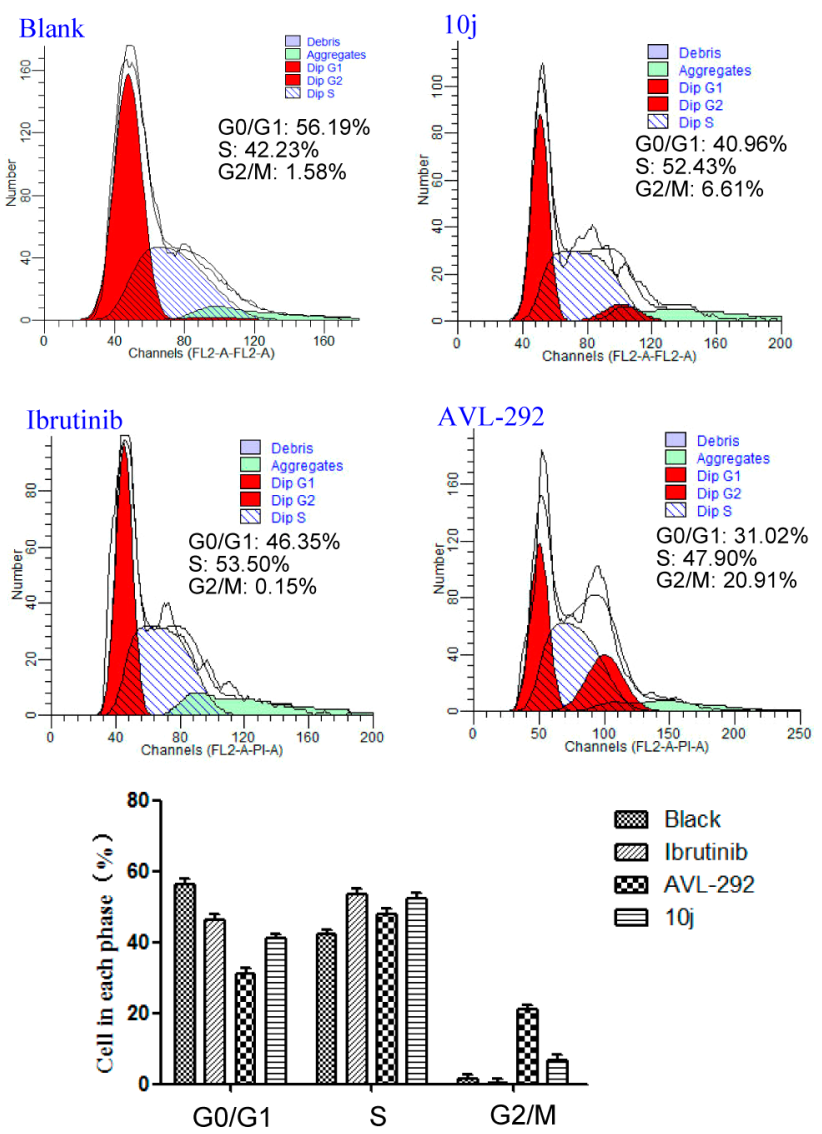

Figure 5. Effects of AVL-292, ibrutinib, and 10j on ramos cell cycle arrest detected by flow cytometry assay. Results are representative of three separate experiments. Data are expressed as the mean \pm standard deviation. $p<0.05$.

position of the phenyl ring was not particularly sensitive to the B-cell leukemia cell lines with an IC $_{50}$ value of more than 40 $\mu \mathrm{M}$. The two compounds 101 and $10 \mathrm{~m}$ containing a special hydroxyl group on the purin core were also not very effective against the B-cell leukemia cell lines, with moderate anti-B-cell leukemia cell lines.

Additionally, the effects of the most active inhibitor $10 \mathbf{j}$ on apoptosis and on the cell cycle in ramos cell line were also determined using flow cytometry analysis in parallel with AVL292 and iburtinib as the reference compounds. As shown in Figure 4, at a concentration of $10 \mu \mathrm{mol} / \mathrm{L}$, all molecules 10 j, AVL-292, and iburtinib induced significant apoptosis (more than $41.5 \%)$. In accordance with their activity against the ramos cell line, the novel inhibitor $10 \mathbf{j}(52.8 \%)$ displayed stronger activity to induce apoptosis than AVL-292 (41.5\%) and ibrutinib (47.9\%). Cell cycle analysis using flow cytometry was also performed for inhibitor 10j. As shown in Figure 5, at a concentration of $10 \mu \mathrm{mol} / \mathrm{L}$, both the new synthesized molecule 10j and ibrutinib produced similar inhibition results arresting the cell cycle at the $S$ phase. By contrast, inhibitor AVL-292 apparently arrested the cell cycle at the G2 phase.

To understand how the newly designed compounds interacted with the ATP-binding pocket of the BTK kinase domain and how this related to their binding affinity for BTK, several representative compounds, specifically the potent inhibitors 10d, 10i, and $10 \mathbf{j}$ and the less active inhibitor 10e, were docked using a molecular simulation into the ATP binding pocket of BTK enzyme (PDB: 3 GEN). ${ }^{27}$ The program

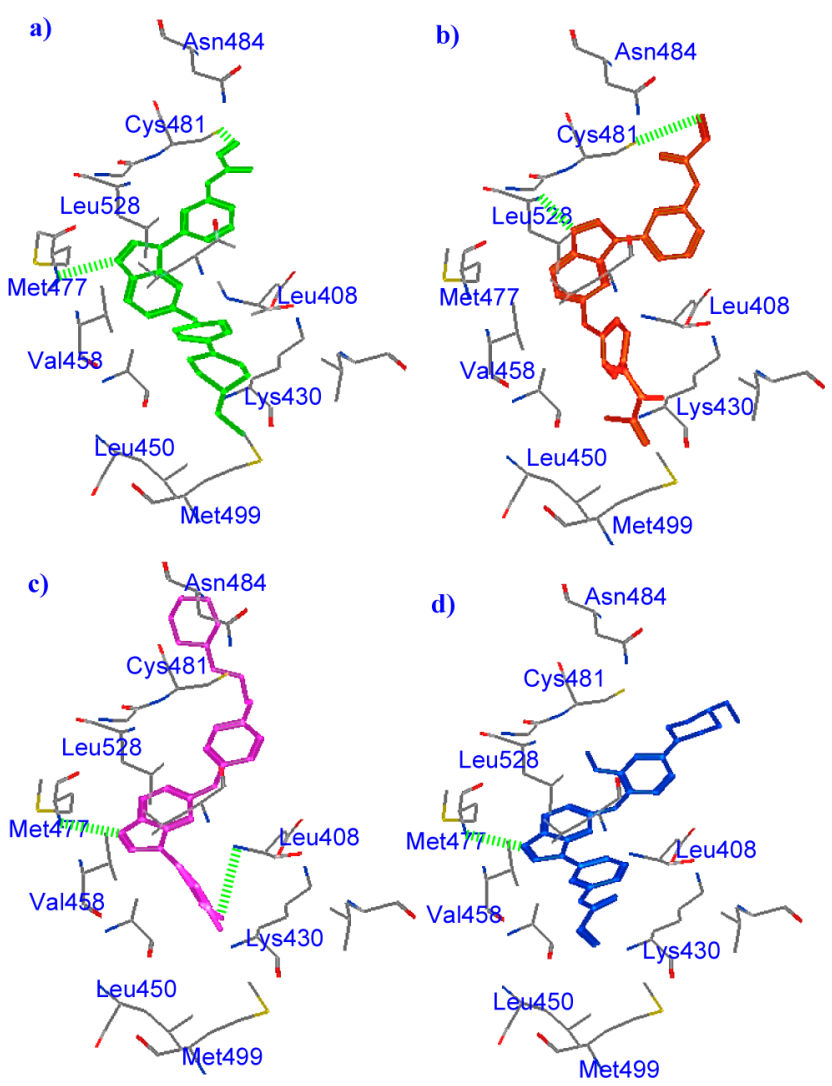

Figure 6. (a) Putative binding model of inhibitor 10d within BTK (PDB code: 3GEN). (b) Putative binding model of inhibitor 10i within BTK (PDB code: 3GEN). (c) Putative binding model of inhibitor 10j within BTK (PDB code: 3 GEN). (d) Putative binding model of inhibitor 10e within BTK (PDB code: 3GEN).

AutoDock 4.2 with its default parameters was used to perform these simulations (Figure 6). ${ }^{28,29}$

As indicated in the model, both active inhibitors $10 \mathrm{~d}$ and $\mathbf{1 0 j}$ formed a strong hydrogen bond between the $\mathrm{N}-7$ atom of purin core and amino acid Met477. While for compound 10i, the strong hydrogen-bond forces were produced by its $N-9$ atom of purin core with Leu528. It also should be noted that in the case of the active inhibitors 10d (Figure 6a) and 10i (Figure 6b), the electrophilic acrylamide was poised in a suitable position to allow the formation of a covalent bond with Cys481, while in compound 10j (Figure 6c) and 10e (Figure 6d), this enhanced interaction was not present. Instead, the polar morpholine ring in $10 \mathbf{j}$ and $10 \mathrm{e}$ pointed directly into the exterior water through a rather small channel in the protein surface, and the 4-aniline group tightly interacted with the hydrophobic pocket surrounded by Lys430, Leu408, and Leu450. Compared with 10e, inhibitor 10j also produced another hydrogen bond between the carbonyl group with amino acid Leu 408 . Moreover, the more flexible morpholine side chain may generate stronger forces with Asn484 and Cys481. Therefore, compound $10 \mathrm{j}$ retained a high potency for inhibiting BTK kinase despite the disappearance of a covalent bond. Taken together, the docking simulation provided the possible explanations for the experimentally observed activities.

In summary, a series of novel N,9-diphenyl-9H-purin-2amine derivatives were found to be potent BTK inhibitors. Among these compounds, inhibitors 10d, 10i, and 10j with $\mathrm{IC}_{50}$ values of $0.5,0.5$, and $0.4 \mathrm{nM}$, displayed a level of antiBTK activity that was similar to the reference compounds. 
Moreover, several compounds exhibited potent inhibition for the proliferation of two typical cancer cell lines expressing high levels of BTK, including the ramos and raji cell lines. In particular, compound $10 \mathbf{j}$ was able to suppress these cell lines at concentrations of 7.75 and $12.6 \mu \mathrm{M}$. Apoptosis analysis in the ramos cell line also indicated that $\mathbf{1 0} \mathbf{j}$ was slightly more potent than AVL-292 and ibrutinib. A molecular simulation analysis showed that 10j formed strong interactions with BTK kinase. All these results suggested that $\mathbf{1 0 j}$ was the most active inhibitor, which will be the subject of future experimental studies.

\section{ASSOCIATED CONTENT}

\section{S Supporting Information}

The Supporting Information is available free of charge on the ACS Publications website at DOI: 10.1021/acsmedchemlett.6b00235.

Full experimental details, enzymatic-activity assay, and tumor cellular-activity assay (PDF)

\section{AUTHOR INFORMATION}

\section{Corresponding Author}

*(X.M.) E-mail: xiaodong.ma@139.com.

\section{Author Contributions}

"These authors contributed equally to this work.

\section{Funding}

We are grateful to the National Natural Science Foundation of China (No. 81402788) and the Ph.D. Start-up Fund of Natural Science Foundation of Liaoning Province, China (No. 20141115) for the financial support of this research.

\section{Notes}

The authors declare no competing financial interest.

\section{ABBREVIATIONS}

BTK, Bruton's tyrosine kinase; EGFR ${ }^{\mathrm{T} 790 \mathrm{M}}$, EGFR with T790M mutation; NSCLC, nonsmall-cell lung cancer

\section{REFERENCES}

(1) Küppers, R. Mechanisms of B-cell lymphoma pathogenesis. Nat. Rev. Cancer 2005, 5, 251-262.

(2) Nakken, B.; Munthe, L. A.; Konttinen, Y. T.; Sandberg, A. K.; Szekanecz, Z.; Alex, P.; Szodoray, P. B-cells and their targeting in rheumatoid arthritis-current concepts and future perspectives. Autoimmun. Rev. 2011, 11, 28-34.

(3) Rickert, R. C. New insights into pre-BCR and BCR signaling with relevance to B cell malignancies. Nat. Rev. Immunol. 2013, 13, 578591.

(4) Davis, R. E.; Ngo, V. N.; Lenz, G.; Tolar, P.; Young, R. M.; Romesser, P. B.; Kohlhammer, H.; Lamy, L.; Zhao, H.; Yang, Y.; Xu, W.; Shaffer, A. L.; Wright, G.; Xiao, W.; Powell, J.; Jiang, J. K.; Thomas, C. J.; Rosenwald, A.; Ott, G.; Muller-Hermelink, H. K.; Gascoyne, R. D.; Connors, J. M.; Johnson, N. A.; Rimsza, L. M.; Campo, E.; Jaffe, E. S.; Wilson, W. H.; Delabie, J.; Smeland, E. B.; Fisher, R. I.; Braziel, R. M.; Tubbs, R. R.; Cook, J. R.; Weisenburger, D. D.; Chan, W. C.; Pierce, S. K.; Staudt, L. M. Chronic active B-cellreceptor signaling in diffuse large B-cell lymphoma. Nature 2010, 463, $88-92$.

(5) Pan, Z.; Scheerens, H.; Li, S. J.; Schultz, B. E.; Sprengeler, P. A.; Burrill, L. C.; Mendonca, R. V.; Sweeney, M. D.; Scott, K. C.; Grothaus, P. G.; Jeffery, D. A.; Spoerke, J. M.; Honigberg, L. A.; Young, P. R.; Dalrymple, S. A.; Palmer, J. T. Discovery of selective irreversible inhibitors for Bruton's tyrosine kinase. ChemMedChem 2007, 2, 58-61.
(6) Honigberg, L. A.; Smith, A. M.; Sirisawad, M.; Verner, E.; Loury, D.; Chang, B.; Li, S.; Pan, Z.; Thamm, D. H.; Miller, R. A.; Buggy, J. J. The Bruton tyrosine kinase inhibitor PCI-32765 blocks B-cell activation and is efficacious in models of autoimmune disease and B-cell malignancy. Proc. Natl. Acad. Sci. U. S. A. 2010, 107, 1307513080.

(7) de Rooij, M. F.; Kuil, A.; Geest, C. R.; Eldering, E.; Chang, B. Y.; Buggy, J. J.; Pals, S.; Spaargaren, T. M. The clinically active BTK inhibitor PCI-32765 targets B-cell receptor- and chemokine-controlled adhesion and migration in chroni lymphocytic leukemia. Blood 2012, $119,2590-2594$.

(8) Akinleye, A.; Chen, Y.; Mukhi, N.; Song, Y.; Liu, D. Ibrutinib and novel BTK inhibitors in clinical development. J. Hematol. Oncol. 2013, 6, 59-67.

(9) Yasuhiro, T.; Yoshizawa, T.; Birkett, J. T.; Kawabata, K. ONO4059, A novel Bruton's tyrosine kinase (Btk) Inhibitor: synergistic activity in combination with chemotherapy in a ABC-DLBCL cell line. Blood 2013, 122, 5151-5151.

(10) Lou, Y.; Owens, T. D.; Kuglstatter, A.; Kondru, R. K.; Goldstein, D. M. Bruton's tyrosine kinase inhibitors: approaches to potent and selective inhibition, preclinical and clinical evaluation for inflammatory diseases and B cell malignancies. J. Med. Chem. 2012, 55, 4539-4550.

(11) Xu, D.; Kim, Y.; Postelnek, J.; Vu, M. D.; Hu, D. Q.; Liao, C.; Bradshaw, M.; Hsu, J.; Zhang, J.; Pashine, A.; Srinivasan, D.; Woods, J.; Levin, A.; O’Mahony, A.; Owens, T. D.; Lou, Y.; Hill, R. J.; Narula, S.; DeMartino, J.; Fine, J. S. RN486, a selective Bruton's tyrosine kinase inhibitor, abrogates immune hypersensitivity responses and arthritis in rodents. J. Pharmacol. Exp. Ther. 2012, 341, 90-103.

(12) Evans, E.; Ponader, S.; Karp, R.; Tester, R.; Sheets, M.; Aslanian, S.; St Martin, T.; Zhu, Z.; Chaturvedi, P.; Witowski, S.; Lounsbury, H.; Stiede, K.; Burger, J.; Petter, R.; Singh, J.; Westlin, W. F. Covalent inhibition of Btk with clinical development compound AVL-292 disrupts signaling that maintains the microenvironment necessary for chronic lymphocytic leukemia growth. Clin. Lymphoma Myeloma Leuk. 2011, 11, S173-S174.

(13) Park, J. K.; Byun, J. Y.; Park, J. A.; Kim, Y. Y.; Lee, Y. J.; Oh, J. I.; Jang, S. Y.; Kim, Y. H.; Song, Y. W.; Son, J.; Suh, K. H.; Lee, Y. M.; Lee, E. B. HM71224, a novel Bruton's tyrosine kinase inhibitor, suppresses B cell and monocyte activation and ameliorates arthritis in a mouse model: a potential drug for rheumatoid arthritis. Arthritis Res. Ther. 2016, 18, 91-99.

(14) Li, X.; Zuo, Y.; Tang, G.; Wang, Y.; Zhou, Y.; Wang, X.; Guo, T.; Xia, M.; Ding, N.; Pan, Z. Discovery of a series of 2,5diaminopyrimidine covalent irreversible inhibitors of Bruton's tyrosine kinase with in vivo antitumor activity. J. Med. Chem. 2014, 57, 51125128.

(15) Copeland, R. A.; Pompliano, D. L.; Meek, T. D. Drug-target residence time and its implications for lead optimization. Nat. Rev. Drug Discovery 2006, 5, 730-739.

(16) Brown, J. R. Ibrutinib (PCI-32765), the first BTK (Bruton's tyrosine kinase) inhibitor in clinical trials. Curr. Hematol. Malig. Rep. 2013, 8, 1-6.

(17) Zhou, W.; Ercan, D.; Chen, L.; Yun, C. H.; Li, D.; Capelletti, M.; Cortot, A. B.; Chirieac, L.; Iacob, R. E.; Padera, R.; Engen, J. R.; Wong, K. K.; Eck, M. J.; Gray, N. S.; Jänne, P. A. Novel mutant selective EGFR kinase inhibitors against EGFR T790M. Nature 2009, 462, 1070-1074.

(18) Flanagan, M. E.; Abramite, J. A.; Anderson, D. P.; Aulabaugh, A.; Dahal, U. P.; Gilbert, A. M.; Li, C.; Montgomery, J.; Oppenheimer, S. R.; Ryder, T.; Schuff, B. P.; Uccello, D. P.; Walker, G. S.; Wu, Y.; Brown, M. F.; Chen, J. M.; Hayward, M. M.; Noe, M. C.; Obach, R. S.; Philippe, L.; Shanmugasundaram, V.; Shapiro, M. J.; Starr, J.; Stroh, J.; Che, Y. Chemical and computational methods for the characterization of covalent reactive groups for the prospective design of irreversible inhibitors. J. Med. Chem. 2014, 57, 10072-10079.

(19) Walter, A. O.; Sjin, R. T.; Haringsma, H. J.; Ohashi, K.; Sun, J.; Lee, K.; Dubrovskiy, A.; Labenski, M.; Zhu, Z.; Wang, Z.; Sheets, M.; Martin, T. T.; Karp, R.; van Kalken, D.; Chaturvedi, P.; Niu, D.; Nacht, M.; Petter, R. C.; Westlin, W.; Lin, K.; Jaw-Tsai, S.; Raponi, M.; Van 
Dyke, T.; Etter, J.; Weaver, Z.; Pao, W.; Singh, J.; Simmons, A. D.; Harding, T. C.; Allen, A. Discovery of a mutant-selective covalent inhibitor of EGFR that overcomes T790M-mediated resistance in NSCLC. Cancer Discovery 2013, 3, 1404-1415.

(20) Finlay, M. R.; Anderton, M.; Ashton, S.; Ballard, P.; Bethel, P. A.; Box, M. R.; Bradbury, R. H.; Brown, S. J.; Butterworth, S.; Campbell, A.; Chorley, C.; Colclough, N.; Cross, D. A.; Currie, G. S.; Grist, M.; Hassall, L.; Hill, G. B.; James, D.; James, M.; Kemmitt, P.; Klinowska, T.; Lamont, G.; Lamont, S. G.; Martin, N.; McFarland, H. L.; Mellor, M. J.; Orme, J. P.; Perkins, D.; Perkins, P.; Richmond, G.; Smith, P.; Ward, R. A.; Waring, M. J.; Whittaker, D.; Wells, S.; Wrigley, G. L. Discovery of a potent and selective EGFR inhibitor (AZD9291) of both sensitizing and T790M resistance mutations that spares the wild type form of the receptor. J. Med. Chem. 2014, 57, 8249-8267.

(21) Chang, S.; Zhang, L.; Xu, S.; Luo, J.; Lu, X.; Zhang, Z.; Xu, T.; Liu, Y.; Tu, Z.; Xu, Y.; Ren, X.; Geng, M.; Ding, J.; Pei, D.; Ding, K. Design, synthesis, and biological evaluation of novel conformationally constrained inhibitors targeting epidermal growth factor receptor threonine790 $\rightarrow$ methionine790 mutant. J. Med. Chem. 2012, 55, 27112723.

(22) Xu, T.; Zhang, L.; Xu, S.; Yang, C. Y.; Luo, J.; Ding, F.; Lu, X.; Liu, Y.; Tu, Z.; Li, S.; Pei, D.; Cai, Q.; Li, H.; Ren, X.; Wang, S.; Ding, K. Pyrimido $[4,5-d]$ pyrimidin-4(1H)-one derivatives as selective inhibitors of EGFR threonine790 to methionine790 (T790M) mutants. Angew. Chem., Int. Ed. 2013, 52, 8387-8390.

(23) Zhou, W.; Liu, X.; Tu, Z.; Zhang, L.; Ku, X.; Bai, F.; Zhao, Z.; $\mathrm{Xu}, \mathrm{Y}$;; Ding, K.; Li, H. Discovery of pteridin- $7(8 H)$-one-based irreversible inhibitors targeting the epidermal growth factor receptor (EGFR) kinase T790M/L858R mutant. J. Med. Chem. 2013, 56, $7821-7837$

(24) Lum, C.; Kahl, J.; Kessler, L.; Kucharski, J.; Lundström, J.; Miller, S.; Nakanishi, H.; Pei, Y.; Pryor, K.; Roberts, E.; Sebo, L.; Sullivan, R.; Urban, J.; Wang, Z. 2,5-Diaminopyrimidines and 3,5disubstituted azapurines as inhibitors of glycogen synthase kinase-3 (GSK-3). Bioorg. Med. Chem. Lett. 2008, 18, 3578-3581.

(25) The spectrum data for representative compound $\mathrm{N}$-(9-(3aminophenyl)purin-2-((4-(1-morpholino)propoxyl)aminophenyl)) acrylamide (10j). Yield: $29.1 \%$; off-white solid; ${ }^{1} \mathrm{H}$ NMR (DMSO- $d_{6}$ ) $\delta 1.82-1.87(\mathrm{~m}, 2 \mathrm{H}), 2.36-2.41(\mathrm{~m}, 6 \mathrm{H}), 3.51-3.62(\mathrm{~m}, 4 \mathrm{H}), 3.91(\mathrm{t}$, $J=6.4 \mathrm{~Hz}, 2 \mathrm{H}), 5.83(\mathrm{~d}, J=10.0 \mathrm{~Hz}, 1 \mathrm{H}), 6.33(\mathrm{~d}, J=16.8 \mathrm{~Hz}, 1 \mathrm{H})$, 6.48-6.55 (m, 1H), $6.78(\mathrm{~d}, J=8.8 \mathrm{~Hz}, 2 \mathrm{H}), 7.51-7.66(\mathrm{~m}, 3 \mathrm{H}), 7.68$ $(\mathrm{t}, J=8.8 \mathrm{~Hz}, 2 \mathrm{H}), 8.38(\mathrm{~s}, 1 \mathrm{H}), 8.57(\mathrm{~s}, 1 \mathrm{H}), 8.89(\mathrm{~s}, 1 \mathrm{H}), 9.55(\mathrm{~s}$, $1 \mathrm{H}), 10.48(\mathrm{~s}, 1 \mathrm{H}) ;{ }^{13} \mathrm{C}$ NMR (DMSO- $\left.d_{6}\right) \delta 26.1,53.5(2 \mathrm{C}), 55.0$, 66.0, 66.3 (2C), 114.4 (2C), 114.5, 118.4, 118.6, 120.5 (2C), 127.7, $128.0,130.1,131.7,133.8,135.0,140.1,142.2,150.0,151.8,153.5$, 157.1, 163.5; HRMS (ESI) for $\mathrm{C}_{27} \mathrm{H}_{29} \mathrm{~N}_{7} \mathrm{O}_{3},[\mathrm{M}+\mathrm{H}]^{+}$calcd, 500.2405; found, 500.2396 .

(26) Wu, H.; Wang, W.; Liu, F.; Weisberg, E. L.; Tian, B.; Chen, Y.; Li, B.; Wang, A.; Wang, B.; Zhao, Z.; McMillin, D. W.; Hu, C.; Li, H.; Wang, J.; Liang, Y.; Buhrlage, S. J.; Liang, J.; Liu, J.; Yang, G.; Brown, J. R.; Treon, S. P.; Mitsiades, C. S.; Griffin, J. D.; Liu, Q.; Gray, N. S. Discovery of a potent, covalent BTK inhibitor for B-cell lymphoma. ACS Chem. Biol. 2014, 9, 1086-1091.

(27) Marcotte, D. J.; Liu, Y. T.; Arduini, R. M.; Hession, C. A.; Miatkowski, K.; Wildes, C. P.; Cullen, P. F.; Hong, V.; Hopkins, B. T.; Mertsching, E.; Jenkins, T. J.; Romanowski, M. J.; Baker, D. P.; Silvian, L. F. Structures of human Bruton's tyrosine kinase in active and inactive conformations suggest a mechanism of activation for TEC family kinases. Protein Sci. 2010, 19, 429-439.

(28) Goodsell, D. S.; Morris, G. M.; Olson, A. J. Automated docking of flexible ligands: applications of autodock. J. Mol. Recognit. 1996, 9, $1-5$.

(29) Liang, Y. H.; Feng, X. Q.; Zeng, Z. S.; Chen, F. E.; Balzarini, J.; Pannecouque, C.; De Clercq, E. Design, synthesis, and SAR of naphthyl-substituted diarylpyrimidines as non-nucleoside inhibitors of HIV-1 reverse transcriptase. ChemMedChem 2009, 4, 1537-1545. 